\title{
INVESTIGATION OF POLYCRYSTALLINE LCMO FILMS BY STRONG MICROWAVE AND DC ELECTRIC FIELDS
}

\author{
A. Lučun, F. Anisimovas, O. Kiprijanovič, A. Maneikis, Ž. Kavaliauskas, \\ J. Gradauskas, A. Sužiedèlis, B. Vengalis, and S. Ašmontas \\ Semiconductor Physics Institute, A. Goštauto 11, LT-01108 Vilnius, Lithuania \\ E-mail: as@pfi.lt
}

Received 9 December 2005

\begin{abstract}
We present the results of experimental study of electrical properties of textured $\mathrm{La}_{0.7} \mathrm{Ca}_{0.3} \mathrm{MnO}_{3}$ manganite films, grown onto $\mathrm{MgO}$ substrate by laser deposition technique, under influence of high power microwave radiation and strong pulsed DC electric field of nanoseconds duration. Microwave response data of pure polycrystalline $\mathrm{La}_{0.7} \mathrm{Ca}_{0.3} \mathrm{MnO}_{3}$ films grown onto $\mathrm{ZrO} / \mathrm{MgO}$ substrate is also presented for comparison. Decrease of electrical resistance of the $\mathrm{LCMO} / \mathrm{MgO}$ film was observed in the DC electric field at temperatures ranging from 300 down to $78 \mathrm{~K}$. Nonbolometric character of the resistance increase of the textured $\mathrm{LCMO} / \mathrm{MgO}$ film could be explained by carrier tunnelling through the intergrain boundaries in the strong electric field. Temperature dependence of the resistance change of the $\mathrm{LCMO} / \mathrm{MgO}$ film in the microwave electric field qualitatively followed the dependence of the electrical resistance derivative with respect to temperature, however the characteristic anomaly related to the PM-FM transition in the material in this case was shifted slightly to the lower temperature region. Time dependences of microwave response of the textured $\mathrm{LCMO} / \mathrm{MgO}$ film have shown fast rise of the electrical resistance change when the microwave pulse was applied, and relativelly slow relaxation after the end of the pulse, what is related with heat transfer processes from the manganite film to the substrate.
\end{abstract}

Keywords: manganites, polycrystals, microwaves, strong electric field

PACS: 75.47.Gk, 75.47.Lx, 07.57.Kp

\section{Introduction}

The rare earth manganites, $\mathrm{La}_{1-x} \mathrm{~A}_{x} \mathrm{MnO}_{3}(\mathrm{~A}=$ $\mathrm{Ca}, \mathrm{Sr}, \mathrm{Ba}$ ) exhibiting interesting electrical and magnetic properties such as "colossal" magnetoresistance $[1,2]$, phase transition from high resistance paramagnetic (PM) to metallic ferromagnetic (FM) state at Curie temperature $\left(T_{\mathrm{C}} \cong 100-350 \mathrm{~K}\right)$ and presence of polarized carriers at $T<T_{\mathrm{C}}$ provide increasing interest both for fundamental studies and various applications. The materials prepared in a form of thin films are promising for fabrication of magnetic field sensors, microwave radiation detectors, and novel spintronics devices based on spin-polarized electronic transport in tunnelling heterostructures.

Recent studies of microwave (MW) response of high crystalline quality epitaxial $\mathrm{La}_{0.67} \mathrm{Ca}_{0.33} \mathrm{MnO}_{3}$ (LCMO) films revealed clear evidence of dynamical coexistence of paramagnetic and ferromagnetic phases in a narrow temperature region below the characteristic Curie temperature $T_{\mathrm{C}}$ [3]. Similar investigations performed for polycrystalline manganite films revealed a key importance of intergrain boundaries on high frequency electrical conductivity [4]. Our recent investigations of electrical transport in polycrystalline manganite films by applying strong electrical field (both DC and MW) have showed new promising possibilities to study various electrical current mechanisms in the manganite films [5]. However, up to date, there is a lack of experimental data concerning strong electrical field effects in polycrystalline manganite films of various crystalline quality.

In order to elucidate the origin of possible current transport mechanisms in polycrystalline manganite films, a comparative experimental study of electrical properties in both fine-grained polycrystalline and textured LCMO films by applying both high power microwave radiation and strong pulsed DC electric field of nanoseconds duration was performed in this work.

\section{Experimental}

The $\mathrm{La}_{0.7} \mathrm{Ca}_{0.3} \mathrm{MnO}_{3}$ (LCMO) films with thickness ranging from 150 to $200 \mathrm{~nm}$ were grown in situ 
at $750{ }^{\circ} \mathrm{C}$ by pulsed laser deposition onto crystalline $\mathrm{MgO}(100)$ substrates and polycrystalline ZrO-buffered $\mathrm{Al}_{2} \mathrm{O}_{3}$. The polycrystalline $\mathrm{ZrO}$ overlayers were prepared by depositing metallic $\mathrm{Zr}$ coatings onto nonheated commercially available polycrystalline $\mathrm{Al}_{2} \mathrm{O}_{3}$ substrates. The $\mathrm{Zr}$ coatings were oxidized by annealing in pure oxygen for $2 \mathrm{~h}$ at $1100^{\circ} \mathrm{C}$ and finally cooled down slowly to a room temperature.

$\mathrm{Nd}^{3+}$ YAG laser used for LCMO film deposition operated in a doubled frequency mode $(\lambda=532 \mathrm{~nm})$. Energy and duration of laser pulses were $25-50 \mathrm{~mJ}$ and 8 $10 \mathrm{~ns}$, respectively. After deposition, the LCMO films were annealed at $750{ }^{\circ} \mathrm{C}$ for $30 \mathrm{~min}$ in oxygen ambient at $1 \mathrm{~atm}$ pressure (for 3 hours) followed by slow cooling down to room temperature.

$\Theta-2 \Theta$ X-ray diffraction (XRD) measurements performed for the LCMO films on crystalline $\mathrm{MgO}$ (100) revealed preferential (001) orientation of crystallites with a certain small amount of misoriented (111) and (110) grains. Meanwhile, fine grain structure characterized by misaligned (100), (111) and (110) grains was found from XRD data for the films prepared onto ZrO-buffered $\mathrm{Al}_{2} \mathrm{O}_{3}$ substrates.

Thin LCMO film stripes $10 \mathrm{~mm}$ long and about $2 \mathrm{~mm}$ wide were prepared for the electrical investigations. Couples of silver coating pads of $1 \mathrm{~mm}$ width were magnetron sputtered onto the films to provide low contact resistance electrodes both for DC and microwave measurements. Small distance between the contact pads (of about $300 \mu \mathrm{m}$ ) enabled one to investigate effects of strong electrical field on electrical transport in the films.

Low-frequency $(f \cong 130 \mathrm{~Hz}$ ) electrical resistance measurements were performed in a wide temperature range ( 78 to $300 \mathrm{~K}$ ) using two-probe $\mathrm{AC}$ technique. Driving AC current of about $1 \mu \mathrm{A}$ was used. Electrical measurements in strong pulsed DC electrical field were performed by applying electrical pulses of rectangular shape with 5-10 ns duration and $0.5 \mathrm{~ns}$ rise time.

For the microwave measurements, the samples were placed into the centre of a lowered rectangular waveguide. The longitudinal axis of the samples was oriented perpendicularly to the wide waveguide walls. In such a case, electrical component of the microwave field was parallel to the film surface. The pulsed microwave radiation with frequency of $10 \mathrm{GHz}$, pulse duration of $2 \mu \mathrm{s}$, repetition rate of $40 \mathrm{~Hz}$, and maximum power up to $8 \mathrm{~kW}$ was applied. The microwave response of the samples was measured by a digital oscilloscope using DC bias current of $40 \mu \mathrm{A}$ and a load resistor $(R=110 \mathrm{k} \Omega)$ connected in series. Tempera-

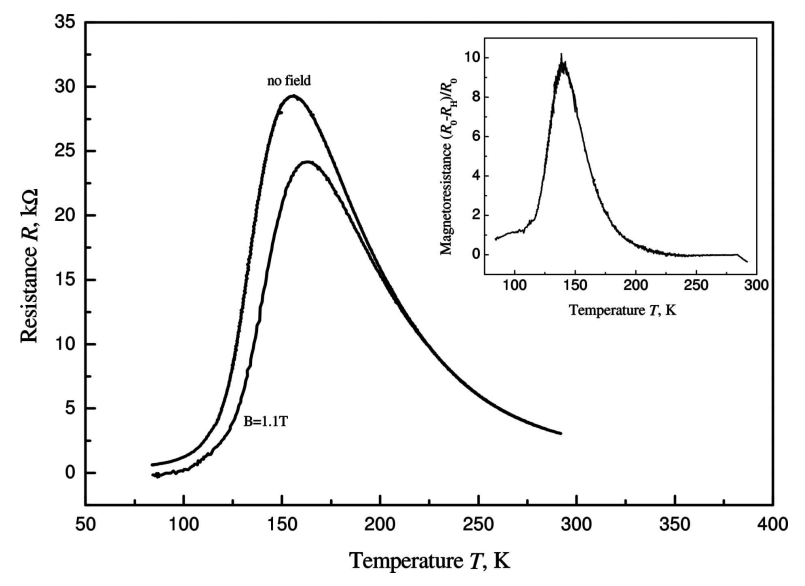

(a)

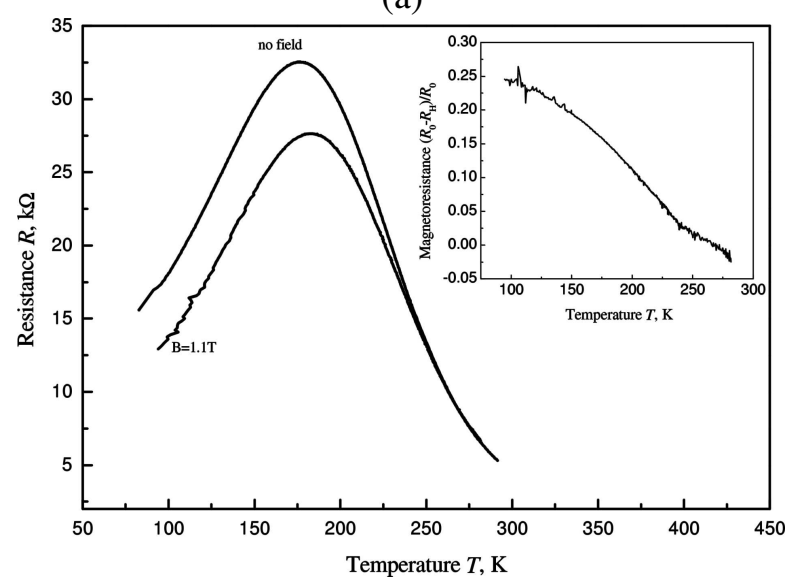

(b)

Fig. 1. Temperature dependence of electrical resistance of (a) textured $\mathrm{La}_{0.7} \mathrm{Ca}_{0.3} \mathrm{MnO}_{3} / \mathrm{MgO}$ and (b) polycrystalline $\mathrm{La}_{0.7} \mathrm{Ca}_{0.3} \mathrm{MnO}_{3} / \mathrm{ZrO} / \mathrm{Al}_{2} \mathrm{O}_{3}$ manganite films. Temperature dependences of the magnetoresistance ratio (at $B=1.1 \mathrm{~T}$ ) are presented in the insets.

ture of the samples controlled by a copper/ constantan thermocouple was stabilised by a certain fixed liquid nitrogen vapour flow.

\section{Results and discussion}

Low-frequency electrical resistance measurements showed that the resistance of fine-grained polycrystalline LCMO films on $\mathrm{ZrO} / \mathrm{Al}_{2} \mathrm{O}_{3}$ substrate was higher compared to that of LCMO films prepared at the same deposition conditions onto crystalline $\mathrm{MgO}$ (see the corresponding $R-T$ plots displayed in Fig. 1). The LCMO films grown onto $\mathrm{ZrO} / \mathrm{Al}_{2} \mathrm{O}_{3}$ substrate demonstrated higher magetoresistance values at lower temperatures compared to textured $\mathrm{LCMO} / \mathrm{MgO}$ film.

Figure 2 depicts the plot of the microwave response $U_{\mathrm{d}}$ (the detected voltage $U_{\mathrm{d}}=I_{\mathrm{b}} \Delta R$, where the bias current was kept $40 \mu \mathrm{A}$, and $\Delta R=R-R_{0}$ is the microwave field-induced resistance change) versus mi- 


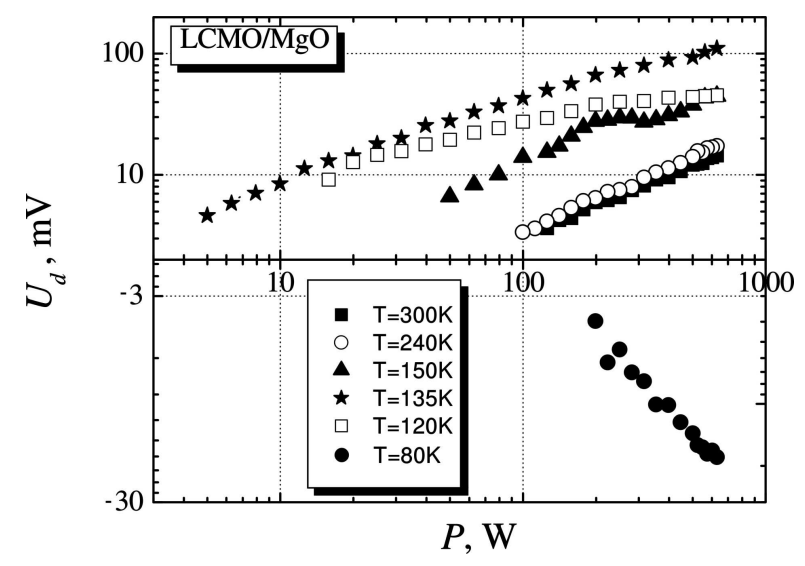

Fig. 2. Voltage-power characteristics of microwave response of the textured LCMO film at various temperatures (bias current $I_{\mathrm{b}}=$ $40 \mu \mathrm{A})$.

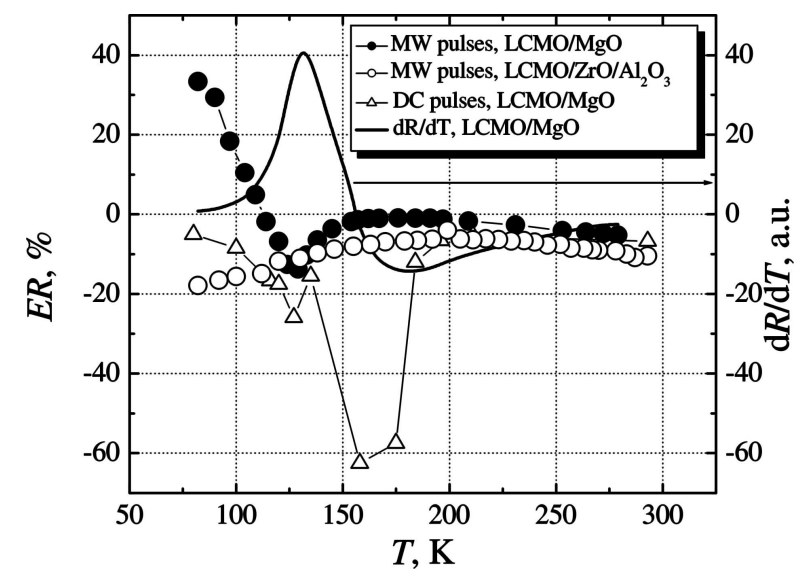

Fig. 3. Temperature dependences of electroresistance of the textured and polycrystalline manganite films under the influence of microwave and pulsed DC electric fields.

crowave power, $P$, for the textured $\mathrm{La}_{0.7} \mathrm{Ca}_{0.3} \mathrm{MnO}_{3} /$ $\mathrm{MgO}$ film. Above the PM-FM transition temperature ( $T_{\mathrm{C}} \approx 150 \mathrm{~K}$ ), the dependence of $U_{\mathrm{d}}$ versus $P$ was found to be linear up to the highest microwave power values $(P \leq 6 \mathrm{~kW})$. The measurements performed at lower temperatures (at $T<T_{\mathrm{C}}$ ) revealed sublinear $U_{\mathrm{d}}(P)$ law. The sublinearity was found to increase with lower temperature while, at liquid nitrogen temperature the $U_{\mathrm{d}}(P)$ dependence became linear again, although in this case we point out an increase of film resistance by applying MW radiation in contrast to significant decrease at higher temperatures $(T>150 \mathrm{~K})$.

Solid points in Fig. 3 represent temperature dependence of the MW-induced resistance change called hereafter as "electroresistance" $E R=[R(E)-R(0)] /$ $R(0)$, where $R(E)$ is film resistance at a certain electric field strength, $E$, and $R(0)$ is zero-field resistance. Solid line corresponding to the electrical resistance derivative with respect to temperature of the same $\mathrm{LCMO} / \mathrm{MgO}$ film is plotted in Fig. 3 for comparison. It can be seen that the maximum values of the observed microwave-induced resistance change are shifted to lower temperatures compared to maximum values of the derivative of the electrical resistance.

Open points in Fig. 3 show the temperature dependence of the electroresistance ER of fine-grained polycrystalline $\mathrm{La}_{0.7} \mathrm{Ca}_{0.3} \mathrm{MnO}_{3} / \mathrm{ZrO} / \mathrm{Al}_{2} \mathrm{O}_{3}$ film. In this case, a monotonic increase of negative ER values was observed over the whole temperature range. No sign of the bolometric character of the resistance change was indicated below the PM-FM transition temperature. It is worth to remind that in the case of epitaxial LCMO film, the sign and maximum values of the microwaveinduced resistance change have corresponded well to the derivative of the electrical resistance [3].

Specific behaviour of the electrical resistance obtained for various manganite films may be explained taking into account different grain structure of the $\mathrm{La}_{0.7} \mathrm{Ca}_{0.3} \mathrm{MnO}_{3} / \mathrm{MgO}$ and $\mathrm{La}_{0.7} \mathrm{Ca}_{0.3} \mathrm{MnO}_{3} / \mathrm{ZrO} /$ $\mathrm{Al}_{2} \mathrm{O}_{3}$ films. One can expect that the $\mathrm{La}_{0.7} \mathrm{Ca}_{0.3} \mathrm{MnO}_{3} /$ $\mathrm{ZrO} / \mathrm{Al}_{2} \mathrm{O}_{3}$ film is composed of fine grains of nanometric dimensions separated by high resistance grain boundaries. It can be seen from Fig. 3 that above the PM-FM transition temperature, there is no sufficient difference for current flow in the case of DC or microwave current. Certainly, the grains and the boundaries at $T>T_{\mathrm{C}}$ are both in a paramagnetic state. Below the transition temperature $T_{\mathrm{C}}$, the grains become low resistance ferromagnetic while the boundaries with worse crystalline quality and modified stoichiometry are expected to stay in a paramagnetic state. In the case of DC electric field, the voltage would drop mainly on the intergrain boundaries, while in the case of microwave electric field, the main part of the voltage drops on the grains. Certainly, high frequency MW current may flow via the capacities formed in between the grains. i.e. the boundaries should be "transparent" for the microwave displacement current. The main difference between the $\mathrm{La}_{0.7} \mathrm{Ca}_{0.3} \mathrm{MnO}_{3} / \mathrm{MgO}$ and $\mathrm{La}_{0.7} \mathrm{Ca}_{0.3} \mathrm{MnO}_{3} / \mathrm{ZrO} / \mathrm{Al}_{2} \mathrm{O}_{3}$ films to our mind is a significant difference in size, number, and alignment of grains. In the textured manganite film, the grains are larger and better aligned. Therefore the role of the boundaries in the textured films should be reduced significantly compared to that in fine-grained films. One can conclude therefore that in respect to high frequency current flow, the textured LCMO films are intermediate between fine-grained polycrystalline and epitaxial films. Therefore, one can expect that the grain boundaries should be of greater importance for microwave 


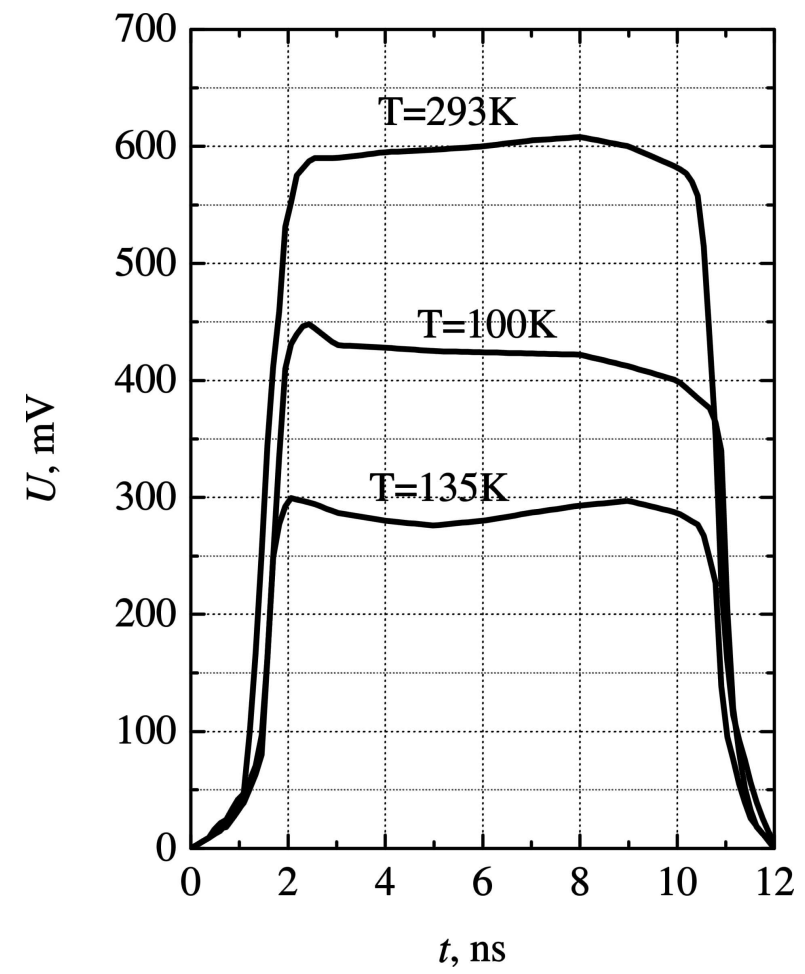

Fig. 4. Pulse shapes of the DC response of the textured LCMO film at various temperatures.

current flowing in a fine-grained policrystalline manganite films.

Electrical transport investigations performed for the manganite films using strong DC electrical field of nanosecond duration gave additional information about the dynamics of the electrical field-induced resistance change for the polycrystalline LCMO films [6]. Triangle-shaped points in Fig. 3 depict the temperature dependence of $E R$ induced by short pulses of strong (up to $10 \mathrm{kV} / \mathrm{cm}$ ) DC electric field. Negative electroresistance values were measured for the textured $\mathrm{La}_{0.7} \mathrm{Ca}_{0.3} \mathrm{MnO}_{3} / \mathrm{MgO}$ film in the entire temperature range. It is important to note that this negative increase of $E R$ is not bolometric by its nature. It can be explained assuming carrier tunnelling through intergrain boundaries under strong electric field [6].

Oscillograms of the response pulse measured for the textured LCMO film at various temperatures by applying square pulses of DC current are presented in Fig. 4. At room temperature $\left(T \gg T_{\mathrm{C}}\right)$, the electrical resistance change was almost constant during the entire duration of the pulse. In the vicinity of the PM-FM transition temperature $(T=135 \mathrm{~K})$, slight decrease and following increase of the resistance change was observed. Monotonic decrease of the resistance change at lower temperature $(T=100 \mathrm{~K})$ observed during the whole pulse duration we associate with Joule heating of the

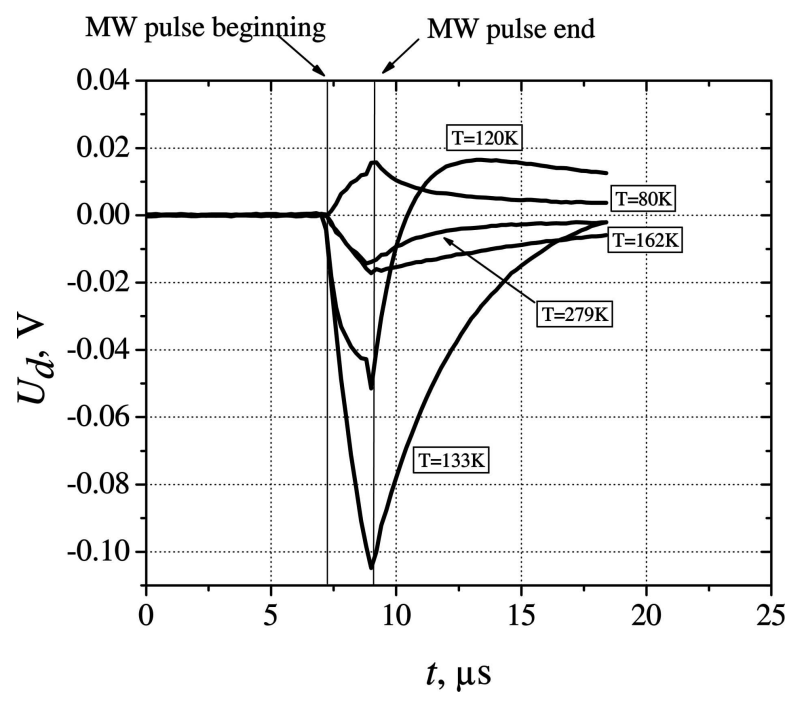

Fig. 5. Pulse shapes of microwave response of the textured LCMO film at various temperatures.

manganite film under the influence of strong electrical field.

Pulsed microwave response measured at various temperatures for textured LCMO film is displayed in Fig. 5. The response rise time was independent of temperature, while the corresponding relaxation time depended on temperature nonmotonically: it rised from about $2 \mu$ s at room temperature up to $10 \mu$ s at the PMFM transition temperature and decreased following the sample cooling below $T_{\mathrm{C}}$. The relaxation time magnitude is determined not only by electrical resistance of the sample, because its value varies from $0.2 \mu$ s at room temperature up to $2 \mu \mathrm{s}$ at the transition temperature. The duration of the microwave response relaxation could be related with heat transfer processes from LCMO film to substrate in the same manner as in the case of epitaxial manganite films [1].

\section{Conclusions}

- Significant decrease of electrical resistance was observed for textured LCMO films in a wide temperature range $(\mathrm{T}=78-300 \mathrm{~K})$ by applying strong $\mathrm{DC}$ electric field. The nonbolometric character of the resistance decrease observed for textured LCMO film is explained within a model based on tunnelling of carriers through intergrain boundaries under strong electrical field.

- Temperature dependence of resistance change of the textured LCMO film in microwave electric field qualitatively followed the temperature dependence of the electrical resistance derivative, however the characteristic anomaly related to the PM-FM tran- 
sition in the material in this case was shifted slightly to the lower temperature region.

- Time dependences of microwave response pulse of the textured LCMO film showed fast rise of the electrical resistance change when microwave pulse was applied, and relatively slow relaxation after the end of the pulse, that is related with heat transfer processes from the LCMO film to the substrate.

\section{Acknowledgement}

This work was partially supported by the EC within the Centres of Excellence project PRAMA.

\section{References}

[1] R. von Helmolt, J. Wecker, B. Holzapfel, L. Schultz, and K. Samwer, Giant negative magnetoresistance in perovskitelike $\mathrm{La}_{2} \mathrm{Ba}_{1 / 3} \mathrm{MnO}_{x}$ ferromagnetic films, Phys. Rev. Lett. 71, 2331-2333 (1993).
[2] S. Jin, T.H. Tiefel, M. McCormack, R.A. Fastnacht, R. Ramesh, and L.H. Chen, Thousandfold change in resistivity in magnetoresistive La-Ca-Mn-O films, Science 264, 413-415 (1994).

[3] A. Lisauskas, A. Sužiedèlis, A. Lučun, A. Oginskis, J. Gradauskas, B. Vengalis, and S. Ašmontas, Microwave response of $\mathrm{La}_{2 / 3} \mathrm{Ca}_{1 / 3} \mathrm{MnO}_{3}$ thin films, Solid State Phenomena 94, 257-260 (2003).

[4] S. Ašmontas, A. Abrutis, J. Gradauskas, A. Lučun, A. Oginskis, V. Plaušinaitienè, A. Sužiedèlis, and B.Vengalis, Phase separation and microwave response of epitaxial and polycrystalline manganite films, Acta Phys. Pol. A 105, 141-147 (2004).

[5] S. Ašmontas, F. Anisimovas, S. Balevičius, P. Cimmperman, J. Gradauskas, A. Lučun, V. Stankevič, A. Sužiedèlis, B. Vengalis, and N. Žurauskienè, Frequency dependence of electrical response of polycrystalline LCMO thin films, Acta Phys. Pol. A 107, 193197 (2005).

[6] P. Cimmperman, V. Stankevič, N. Žurauskienè, S. Balevičius, F. Anisimovas, J. Paršeliūnas, O. Kiprijanovič, and L.L. Altgilbers, Electroresistance of $\mathrm{La}-\mathrm{Ca}-\mathrm{MnO}$ thin films, Acta Phys. Pol. A 105, 107-114 (2004).

\title{
POLIKRISTALINIU LCMO SLUOKSNIU TYRIMAI STIPRIUOSE MIKROBANGIUOSE IR NUOSTOVIUOSE ELEKTRINIUOSE LAUKUOSE
}

\author{
A. Lučun, F. Anisimovas, O. Kiprijanovič, A. Maneikis, Ž. Kavaliauskas, J. Gradauskas, A. Sužiedèlis, \\ B. Vengalis, S. Ašmontas
}

Puslaidininkiu fizikos institutas, Vilnius, Lietuva

\begin{abstract}
Santrauka
Pateikti tekstūrinių $\mathrm{La}_{0,7} \mathrm{Ca}_{0,3} \mathrm{MnO}_{3}$ manganitų sluoksnių, užaugintų ant $\mathrm{MgO}$ padèklų lazerinio garinimo būdu, tyrimų rezultatai stipriuose mikrobangiuose ir nuostoviuose nanosekundžiu trukmès impulsiniuose elektriniuose laukuose. Palyginimui taip pat pateikiami polikristalinių $\mathrm{La}_{0,7} \mathrm{Ca}_{0,3} \mathrm{MnO}_{3}$ sluoksnių, užaugintų ant $\mathrm{ZrO} / \mathrm{MgO}$ padéklų, tyrimai mikrobangiuose laukuose. Nuostoviuose elektriniuose laukuose stebètas $\mathrm{LCMO} / \mathrm{MgO}$ sluoksnio varžos padidejjimas 80-300 K temperatūru ruože. Nebolometrinis tekstūrinio LCMO sluoksnio varžos kitimas žemiau virsmo iš paramagnetinès i feromagnetinę medžiagos fazę temperatūros aiški-
\end{abstract}

namas krūvininkų tuneliavimu per tarpgranulines sritis stipriuose elektriniuose laukuose. LCMO/MgO sluoksnio varžos pokyčio mikrobangiuose elektriniuose laukuose temperatūrinè priklausomybẻ kokybiniu požiūriu atitiko tekstūrinio sluoksnio varžos išvestinès pagal temperatūrą eigą, tačiau virsmo temperatūra mikrobangiame eksperimente buvo pasislinkusi i žemesnių temperatūrų pusę. Tekstūrinio LCMO sluoksnio varžos mikrobangis atsakas pasižymėjo staigiu augimu impulso metu ir palyginti lèta relaksacija pasibaigus mikrobangiam poveikiui; lètas varžos vertès atsistatymas aiškinamas šiluminiu laidumu tarp sluoksnio ir padèklo. 